\title{
Development of Multimedia Based on Autodesk Inventor Software on the Concept of Relative Velocity to Increase Students' Generic Science Skill
}

\author{
Ariyano*, Amay Suherman, Handiansyah Akhmadi \\ Departemen Pendidikan Teknik Mesin, Universitas Pendidikan Indonesia, \\ Jl. Setiabudi No. 229 Bandung \\ *Corresponding author, e-mail: ariyano_iyan@upi.edu
}

\begin{abstract}
This research aims to develop Autodesk inventor-based multimedia that was designed to increase students' generic science skill on the application of relative velocity at kinematics and dynamics courses. This study used the mini course method developed by Borg and Gall, including the stage of analyzing and planning, developing early product, and validating from the expert and revision the early product. Based on the analysis conducted, it was revealed that there were five indicators that students had difficulties with, including illustrating kinematic diagram, illustrating velocity direction, calculating absolute velocity, illustrating velocity polygon, and calculating velocity based on velocity polygon. Those five indicators were related to six generic science aspects, including modelling, symbolic language, laws of causality, logical consistency, scale awareness, and observation. The developed multimedia consists of nine displays of slider-crank mechanism and eight displays of fourbar mechanisms, using .idw, iam, and .mp4 formats and has been validated by material and media experts. Based on the judgment from the experts, the inventor-based multimedia was worthy to be applied in the course.
\end{abstract}

Keywords: multimedia, autodesk inventor, generic science skill, relative velocity

How to Cite: Ariyano, Suherman, A, \& Akhmadi, H. (2020). Development of Multimedia Based on Autodesk Inventor Software on the Concept of Relative Velocity to Increase Students' Generic Science Skill. Journal of Vocational Education Studies, 3(1), 111-122. DOI: https://doi.org/10.12928/ joves.v3i2.2482.

\section{INTRODUCTION}

One of the skills that students need to master in mechanical engineering is generic science skills (Inti, Latib, \& Saud, 2016). Together with discipline knowledge, generic skills from graduates are requested many employers (Neilsen, 2000). Even, employers in the 21st century pay more attention to the generic skill level of prospective workers than technical knowledge when selecting the most suitable candidate from the large group of prospective workers. Managers and industrial workers and polytechnic lecturers are of the view that generic skills are needed by every student who is studying to become a worker. The results of research conducted in Malaysian industry, for instance, reveal that every generic piece of science needed to become a competitive engineer belongs to the high category (Ismail, Hamzah, \& Azid, 2018). Therefore, the generic skills should be embedded into the course.

Kinematics and dynamics is a basic course that contains a fundamental concept needed for later advanced course. Kinematics and dynamics is generally needed in analysing and designing a machine, especially related to movement. The basic concepts of kinematics and dynamics are velocity and relative acceleration that can be used to analyse and design a machine with a slider-crank or four-bar mechanisms (Erdman \& Sandor, 1997; Martin, 2002). It depicts an occurrence of a part in motion. Both slider-crank and four-bar mechanisms are a combination of the rods that each move, so that in explaining it requires media that are not static. However, based on on the pre-eliminary research, the topic was mostly delivered by using simple learning media, involving only texts and images. This affected the student's understanding of the concepts. Moreover, students have difficulty in 
developing generic science skills in the course, including reading or making a chart of a kinematic phenomenon and writing equations for the application of relative acceleration of a certain phenomenon. The ability to reveal a phenomenon using picture sketches or charts is one of the indicators of generic science skill, so called modelling (Agustin, 2013; Sudarmin, 2012). Other generic science skills have been summarized in the previous researches. It includes direct and indirect observation, consciousness about scale, languages, symbolic, logical framework, consistency, logical, the law of cause effect and abstraction skills (Brotosiswoyo, 2000; Sudarmin, 2012; Tawil \& Liliasari, 2014).

Autodesk inventor is one of the engineering applications from Autodesk Corp. used for engineering design and drawing. Autodesk inventor is a development product from AutoCAD and Autodesk Mechanical Desktop (Class-Morales, Leake, \& Hall, 2007 ). The application has display for 3D design along with tension analysis feature and motion animation so that it is considered appropriately for the use of an animation multimedia for kinematics and dynamics course (Wahyudi, Anugrah, \& Adi, 2015). Previous research has also shown that computer media with Autodesk Inventor software is significantly better when compared to learning with conventional methods (Syafrudin, 2019). In addition, the application of animation as a learning media might facilitate student-center learning (Morón-García, 2002) and can contribute a lot to learning outcomes and improve students' physics learning concepts with attitude (Su \& Yeh, 2014).

Based on the description above, this research aims to develop a learning multimedia based on Autodesk Inventor software for kinematics and dynamics topic. The multimedia is designed to develop student's generic science skills.

\section{RESEARCH METHOD}

This research used the mini course development method by Borg and Gall (Gall, Borg, \& Gall, 1996). The steps are as follows:

1. Analysing and planning on the product to be developed. This step is to collect information from library research and learning experiences that have been running so far.

2. Developing early product. This step is to make the initial product through indicators of each character, which has been analyzed and entrusted with the functions, benefits, and convenience of multimedia when used.

3. Expert validation and revision. Multimedia that has been created is validated by media experts and chemist material experts. If there is a revision, then the multimedia product must be improved based on the direction of the experts so that the product continues to the next step.

4. Field testing and product revision. The fourth step is using the product of multimedia, which has been declared feasible by experts, in the classroom. This step allows product revision based on input from the results of field trials.

5. Reporting and applying product. This final step is to discuss the results of applying multimedia classes and can then be used to facilitate students in learning activities.

In this study, we only explain the development up to the third stage, namely the results of multimedia products made and ready for use in classroom research.

\section{RESULTS AND DISCUSSION}




\section{Analysing and planning on product that is going to be developed}

The first step in inventor-based multimedia development is product analysing and planning. This multimedia is planned to facilitate students in increasing generic science aspects on relative velocity subject. Based on the analysis conducted, it was revealed that there are five indicators that students have difficulties with, including illustrating kinematic diagram, illustrating velocity direction on every rod, calculating absolute velocity on a rod, illustrating velocity polygon, and calculating velocity based on velocity polygon. Those five indicators are related to six generic science aspects, including modelling, symbolic language, laws of causality, logical consistency, scale awareness, and observation. These six generic science aspects are contained in the material of the application of relative speed, so that if students are facilitated to improve the generic aspects of science then student learning outcomes will also increase. Table 1 illustrates the indicators and generic aspects of science in the application of the relative velocity that is the main aspects in the development of Inventor-based multimedia.

Table 1. Indicator and generic science skills on relative velocity subject

\begin{tabular}{rll}
\hline No & \multicolumn{1}{c}{ Indicators } & \multicolumn{1}{c}{ Generic Science Skills } \\
\hline $\mathbf{1}$ & Illustrating kinematic diagram & Modelling and symbolic language \\
$\mathbf{2}$ & $\begin{array}{l}\text { Illustrating velocity direction } \\
\text { on every rod }\end{array}$ & $\begin{array}{l}\text { Symbolic language, modelling and laws of } \\
\text { causality }\end{array}$ \\
$\mathbf{3}$ & $\begin{array}{l}\text { Calculating absolute velocity on } \\
\text { a rod }\end{array}$ & $\begin{array}{l}\text { Logical consistency, scale awareness, symbolic } \\
\text { language, and observation }\end{array}$ \\
$\mathbf{4}$ & Illustrating velocity polygon & $\begin{array}{l}\text { Scale awareness, modelling, and symbolic } \\
\text { language }\end{array}$ \\
$\mathbf{5}$ & Calculating velocity based on \\
velocity polygon & $\begin{array}{l}\text { Logical consistency, scale awareness, and } \\
\text { symbolic language }\end{array}$ \\
\hline
\end{tabular}

\section{Developing early product}

The second step in this study was the development of early product. The multimedia product content is designed as such to facilitate students to achieve competence according to indicator and generic science aspects formulated on the previous step. Autodesk inventor application has been chosen as the base multimedia since it is considered appropriate as an animation multimedia. This application is an engineering design and drawing that has display for 3D designing along with analysing and motion animation feature that can be used to facilitate students to solve problems on the subject of application of relative velocity on two mechanisms i.e. slider-crank and four-bar mechanisms.

The multimedia display consists of images, text, video, and motion animation. The slider-crank mechanism has 9 displays and the four-rod mechanism has 8 displays. The displays have been designed not only to guide students in learning and solving problems on the application of relative velocity but also to provide students with the competences that related to the indicators and generic science skills stated in the previous step (Table 1). Figure 1 shows the example of displays to calculate the relative velocity by using polygon. Each display counts the indicators and generic science skills. The completion steps of drawing kinematic diagrams, writing notations, and pointing the notation have been highlighted in the display to facilitate students in the experience of illustrating kinematic diagram indicator (Figure 1). The display also focuses on the completion order, the magnitude of the angle between the speed line and the bar it represents, and writing and designation point of the speed notation to provide students with the competence of drawing the possible direction of speed on each bar (Figure 1). The display emphasizes on the available data, data needed to calculate linear velocity, and units of each scale to improve 
the competence of measuring rod linear velocity (Figure 1). The display focuses on completion steps, units of each scale, and writing and designation of notations on speed polygons to facilitate students in drawing speed polygons and the completion orders and units of each scale to facilitate students in calculating speed based on the speed polygons (Figure 1). In addition, video media depicting speed polygon steps are also contained in the .mp4 video format to make it easier for students to draw speed polygons.

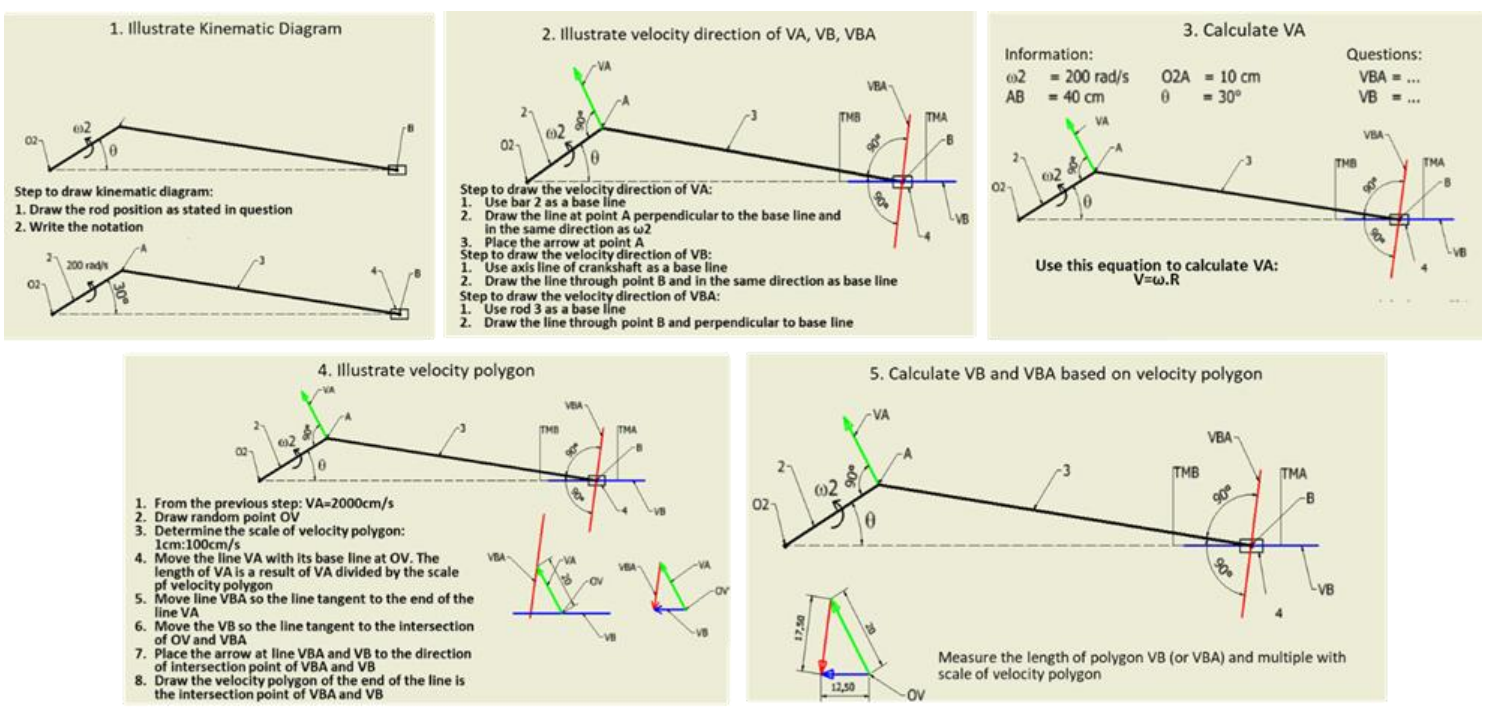

Figure 1. Example of multimedia display developed for indicator of illustrating kinematic diagram (1), illustrating velocity direction on every rod (2), calculating absolute velocity on a rod (3) illustrating velocity polygon (4), and calculating velocity based on velocity polygon (5)

The formats made to operate this multimedia are iam, .idw, dan .mp4 formats. The .iam and idw formats can be operated with Autodesk inventor at least with the 2015 version and with minimum specification as follows: (i) Windows OS 7; (ii) CPU dual core with minimum processing speed of $2.0 \mathrm{GHz}$; (iii) 4 GB RAM; and (iv) 8GB Memory Storage Capacity.

\section{Expert validation and revision}

The third step was validation of the developed multimedia by learning media and kinematic subject experts. The validation by learning media expert was based on aspects of visual communication and software engineering. In general, learning media expert categorized the media was good enough, but there was a need to add the learning media in the video format of mp4. The video format is used to explain the steps of depiction of velocity polygons. In addition, symbols need to be equipped. Whilst the assessment by the material experts concerned on the aspects of learning design. They suggested to add material of a fast turning mechanism and relevance to the learning objectives.

The revision has been made based on the validation of the experts. The multimedia provides the steps to assist students in solving the problem in the concept of velocity and relative acceleration. The revised version of multimedia has nine displays of slider-crank mechanism and eight displays of four-bar mechanisms. Both slider-crank and four-bar mechanisms $s$ have animation display that shows the movement of each of those mechanisms. These animation displays are main key in the learning process since most students have difficulties in illustrating the movement of each rod on both mechanisms. 
After the revision, the inventor-based multimedia was made in three formats, namely the .iam, .idw, and .mp4. Figure 2 shows the example of multimedia display in the iam and .idw formats, while figure 3 in mp4 format. The iam format is used for two animated displays of the movements of the slider-crank and four-bar mechanisms, while the idw format is used for 14 displays, which are dedicated to guide students in problem solving. The video display has .mp4 format and is used to guide students how to draw velocity polygons.

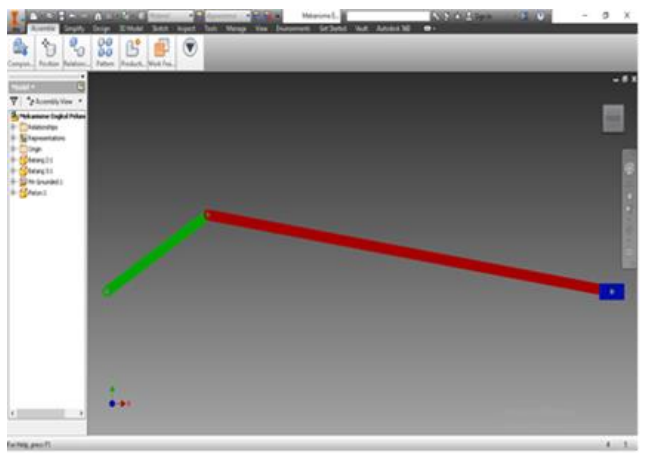

A

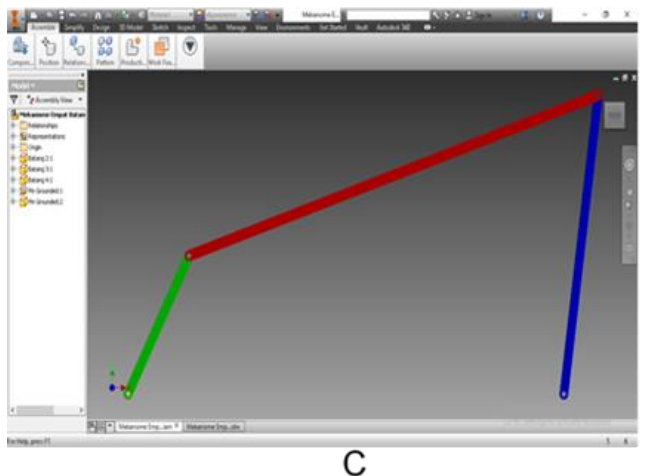

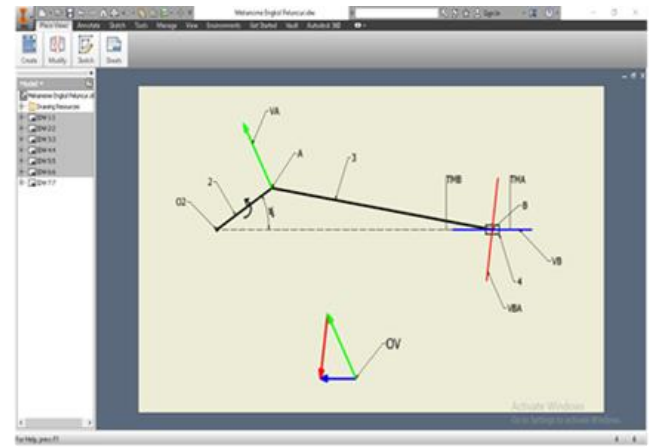

B



D

Figure 2. Examples of animation design of slider crank mechanism in. iam $(A)$ and idw (B) formats and four-bar mechanisms in .iam (C) and .idw (D) formats.

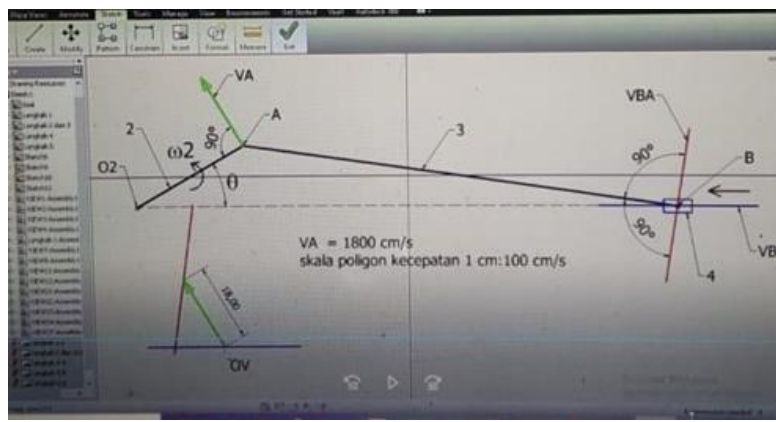

Figure 3. Example of video display of steps to sketch a polygon of velocity slider-crank mechanism in the mp4 format

The application of the multimedia in the class is expected to provide functions and benefits. The previous research has shown that this type of multimedia can function as a messenger, so the course is not too verbalistic and therefore increase students' learning motivation, interests, and getting students be more active in class (Teoh \& Neo, 2007). This typical multimedia also has presented to give students fresh learning experience, to urge students to study on their own and not only listen to lecturer Moreover, kinematics and dynamics course is mostly mathematical, formulative, and consists of abstract concepts. 
Hence, the course need multimedia that can offer a complex occurrence. This complex occurrence presentation can shorten course duration compared with verbal explanation. In addition, the animation multimedia is capable to visualize subject matter that is difficult to elaborate verbally or any conventional tools.

\section{CONCLUSION}

Inventor based multimedia consists of .iam, .idw, and .mp4 formats. Multimedia is operable with video player and Autodesk Inventor application at least with 2015 version. Multimedia consists of nine displays on slider-crank mechanism and eight displays on connecting rods mechanism. Multimedia is ready to use to increase students' generic science skill on relative velocity. Multimedia is designed for student centered learning in a sense that multimedia only facilitates or guide students to achieve indicator competence according with what has been formulated.

\section{REFERENCES}

Agustin, R. R. (2013). Pengembangan keterampilan generik sains melalui penggunaan multimedia interaktif. Jurnal Pengajaran MIPA, 18(2), 253-257.

Brotosiswoyo, B. (2000). Kiat Pembelajaran MIPA dan Kiat Pembelajaran Fisika di Perguruan Tinggi. Jakarta: Departemen Pendidikan Nasional.

Class-Morales, F., Leake, J., \& Hall, B. (2007). Development Of A Standalone Computer Aided Tutorial To Integrate Computational Tools Into A Mechanical Design Curriculum. Paper presented at the Annual Conference \& Exposition, Honolulu, Hawaii. https://peer.asee.org/2157

Erdman, A. G., \& Sandor, G. N. (1997). Mechanism design analysis and synthesis (Vol. 1). Upper Saddle River, New Jersey: Prentice-Hall, Inc.

Gall, M. D., Borg, W. R., \& Gall, J. P. (1996). Educational research: An introduction: Longman Publishing.

Inti, M. M., Latib, A. A., \& Saud, M. S. (2016). The Generic Skills Needed by Mechanical Engineering Students at the Polytechnic level. Jurnal Pendidikan Nusantara April, 2016., Special Edition(April), 294-308.

Ismail, W. W., Hamzah, N., \& Azid, A. (2018). Generic skills requirements (KSA model) towards future mechanical engineers using discriminant analysis. Journal of Fundamental and Applied Sciences, 10(1S), 169-181.

Martin, G. H. (2002). Kinematics and dynamics of machines. Illinois: Waveland Press.

Morón-García, S. (2002). Using virtual learning environments: lecturers' conceptions of teaching and the move to student-centred learning. Paper presented at the International Conference on Computers in Education, 2002. Proceedings.

Neilsen, A. (2000). Employer satisfaction with graduate skills: Commonwealth of Australia, Canberra.

Su, K.-D., \& Yeh, S.-C. (2014). Effective Assessments of Integrated Animations--Exploring Dynamic Physics Instruction for College Students' Learning and Attitudes. Turkish Online Journal of Educational Technology-TOJET, 13(1), 88-99.

Sudarmin, S. (2012). Keterampilan Generik Sains dan Penerapannya dalam Pembelajaran Kimia Organik: Semarang: UNNES Press.

Syafrudin, S. (2019). Penggunakan media komputer dengan perangkat lunak autodesk inventor untuk meningkatkan hasil belajar mata diklat menggambar teknik manufaktur kelas XI program keahlian teknik pemesinan di SMK Negeri 2 Palembang. Paper presented at the Prosiding Seminar Nasional Program Pascasarjana Universitas PGRI Palembang, Palembang.

Tawil, M., \& Liliasari, L. (2014). Keterampilan-keterampilan sains dan implementasinya dalam pembelajaran IPA. Makassar: Universitas Negeri Makasar. 
Teoh, B. S.-P., \& Neo, T.-K. (2007). Interactive Multimedia Learning: Students' Attitudes and Learning Impact in an Animation Course. Online Submission, 6(4).

Wahyudi, W., Anugrah, F., \& Adi, R. (2015). Modul Praktikum CAD-Inventor. Yogyakarta: UMY. 
